\title{
Analysis on carbon footprint: A Case Study of Gorkhapatra National Daily in Nepal
}

\author{
Anukram Sharma $^{a, *}$, Khem N Poudyal ${ }^{a}$ and Nawraj Bhattarai ${ }^{b}$ \\ ${ }^{a}$ Department of Applied Science and Chemical Engineering, Pulchowk Campus, Institute of Engineering, Tribhuvan University, Lalitpur, Nepal \\ ${ }^{b}$ Department of Mechanical and Aerospace Engineering, Pulchowk Campus, Institute of Engineering, Tribhuvan University, Lalitpur, Nepal
}

\section{ARTICLE INFO}

\section{Article history:}

Received 27 Dec 2020

Received in revised form

29 Jan 2021

Accepted 07 Feb 2021

\section{Keywords:}

Newspaper

Climate Change

Carbon Emission

Carbon Footprint

Fuel Consumption

\begin{abstract}
Study of carbon footprint is an emerging field which provides statistical analysis about the contribution of an activity on global climate change. Every human activity in daily life is achieved at the expense of those substances which directly or indirectly contribute to global warming. In this era of global communication, humans are habitual to know about the ongoing changes in the world. Newspapers are one of the reliable sources for getting updated about the global information. Paper-based newspapers come at the cost of greenhouse gas emissions. So, this article based upon an analysis of carbon footprint of Nepal's national daily newspaper provides evaluation of each of the following: carbon emission during the manufacturing of raw materials, carbon emission from fuel consumption during transportation of raw materials, carbon emissions during the printing of newspaper and carbon emission from the fuel consumption during the transportation of printed newspaper. During the study period of 2019 A.D., the result shows that the total carbon emission of Gorkhapatra newspaper was $2213.1 \mathrm{~kg} \mathrm{CO}_{2}$ e per ton for scenario I and $2308.5 \mathrm{~kg} \mathrm{CO}_{2} \mathrm{e}$ per ton for scenario II. The upshot of this study provides not only thorough information about carbon emissions but also builds a foundation for calculation of carbon emissions from paper used in various sectors.
\end{abstract}

CJIEE Thapathali Campus, IOE, TU. All rights reserved

\section{Introduction}

Climate change is the most significant challenge for achieving sustainable development in human society. Extensive utilization of fossil fuels which lead to the emission of greenhouse gases in the atmosphere has already shown its effect in the form of global warming and climate change. The IPCC Special Report on global warming of $1.5^{\circ} \mathrm{C}$ has already mentioned that keeping global warming below $1.5^{\circ} \mathrm{C}$ above the pre-industrial level is only feasible if there is large reduction in the greenhouse gas emissions [1]. Efforts have been made to evaluate, analyze, and reduce the carbon emissions from combustion of fossil fuels from industries and automobiles. In addition to industries and automobiles, many activities performed by humans daily can also generate carbon emissions. Among them newspapers that humans use to gather information about ongoing

\footnotetext{
*Corresponding author:

@sharmanukram@gmail.com (A. Sharma)
}

activities across the globe in the form of paper also come in expense of a significant amount of greenhouse gas emissions.

Newspapers are almost useful for only a short period of time and are often dumped into waste bins after reading once. Municipal solid waste in Nepal is composed of $16 \%$ paper and paper products which include $9 \%$ of household waste, $45 \%$ of institutional wastes and 23\% of commercial waste [2]. Papers are made at the cost of chopping down a large amount of trees. The quantity of carbon in the biomass can vary from 35 to 65 percent of the dry weight (generally 50 percent is taken as a default value) [3]. Plants help to modulate the carbon dioxide in our atmosphere. Harvesting trees to produce newspapers has a direct and notable contribution to climate change. According to the International Panel on Climate Change (IPCC), forestry and deforestation are responsible for as much as 25 percent of the world's human-caused greenhouse gas emissions.

Analysis of carbon footprint refers to the measurement 
of absolute global amount of carbon dioxide and other GHGs attributed by a human activity or accumulated over a life cycle of a product or service. The life cycle concept of the carbon footprint refers to all possible causes that give rise to carbon emissions during a process or service. Usually, a carbon footprint is expressed in terms of $\mathrm{CO}_{2}$ equivalent, which accounts for the same global warming effects of other greenhouse gases [4]. Carbon footprints can either consider only direct emissions or can also include indirect emissions while performing any action or producing any product.

Researches has been carried out all over the world to analyze the carbon footprint of paper using life cycle assessment (LCA), a powerful tool for environmental impact quantification. More than hundreds of studies have been published regarding the different processes of pulp and paper making in different countries which includes paper making in Portuguese pulp and paper industry [5] evaluating chemical, mechanical and biopulping processes and their sustainability characterization in Canada [6], forestry processes in comparative case study in Sweden and Spain [7] and wastewater treatment in terms of wastepaper recycling in Spain [8]. GHG emissions from paper making varies from nations and within regions. Most of the cases in China are found to be at higher emission zones, which accounts over $1500 \mathrm{~kg} \mathrm{CO}_{2}$ e per ton of paper. In one case about $2300 \mathrm{~kg} \mathrm{CO}_{2}$ e per ton was used to produce coated white board by utilization of woodchips and wastepaper [9]. Wood Kraft pulp used to produce tissue paper in Spain was found to consume $1875 \mathrm{~kg} \mathrm{CO}_{2} \mathrm{e}$ where pulp was imported from other European countries and South America [10]. Kraft liner paper in Brazil was found to use only $461 \mathrm{~kg} \mathrm{CO}_{2} \mathrm{e}$ after modernization of boiler from $936 \mathrm{~kg} \mathrm{CO}_{2}$ e before modernization [11]. The variation is GHG emissions from one country to another is due to the variation in the amount of electricity involved in processing, transportation of raw materials, technologies adopted, etc.

In recent years, research has been more focused in analyzing the carbon emissions during the printing of newspaper and comparing them with proper alternatives or reduction potential by using advanced technologies. Research has been carried out in India by Rohit Gupta to analyze the carbon footprint of the newsprint industry using process analysis and Environmental input-output model [12]. Also, the research has been carried out to analyze the effectiveness of electronic invoicing over the paper invoicing in terms of carbon emission reduction by Maija Tenhunen in Finland [13]. Carbon footprint of copying paper is also done in China [14]. The life cycle assessment for printed newspapers is also done in Northwestern Mexico [15]. A comparative life cycle assessment of the daily and weekly magazine is done in Germany [16]. Similarly, the life cycle assessment of printing and writing paper is done in Portugal [17]. Research show that the life cycle assessment of the newspaper is highly affected by the source of energy used in the pulp to paper manufacturing. The published articles demonstrate that the use of renewable or green energy in Europe contributes less GHG emissions compared to Northern America and China. Also, the percentage of recycling of the pulp or paper also contributes to reducing the GHG emissions.

Though the many research is being carried out for estimating carbon footprint of paper in different parts of Europe and Northern America, research is yet to be carried out to analyze the life cycle assessment of the newspaper, in the context of Nepal. This research tries to account the emissions in the transportation of printed newspaper to readers. Further recycling of aluminum plates is not practiced in the Gorkhapatra, which can almost reduce the waste generation to about 51 percent if recycled [18]. The raw materials are imported from the neighboring countries in Nepal which ultimately increases the carbon footprint due to long distance transportation. Also, much research have eliminated the accountings of GHG emissions during the delivery of newspaper to readers due to difficulty in tracing actual distribution pattern. The distribution of printed newspaper over geographically complicated roads is also very challenging. The recycling of the newspaper is in insignificant amounts where the used newspapers are disposed to landfills or burnt. Assessment of carbon emissions from paperbased newspapers in Nepal will itself be a novelty due to geographical divergence, minimum recycling culture, and long-distance transportations. In addition, the research will be insightful on the various activities like use of efficient equipment and techniques to reduce emissions, reducing unnecessary power consumptions and promoting the culture of recycling.

\section{Material and methods}

\subsection{Overview}

An economic survey done by the governmental body of Nepal has shown that there are a total 705 registered daily newspapers in Nepal [19]. Aiming to calculate the carbon footprint of a national daily newspaper in Nepal, it is necessary to define a specific newspaper that will be taken as the basis of analysis for the calculation. This study is entirely based on the case study of Gorkhapatra national daily newspaper. Gorkhapatra is a Nepali-language broadsheet newspaper published and distributed daily in Nepal. Gorkhapatra is one of the oldest national daily newspapers in Nepal which is run by Gorkhapatra Sansthan. Gorkhapatra established 
its printing as a weekly newspaper in 1901 A.D. and later reformed its version as daily newspaper in 1961 A.D. In year 2019 A.D. Gorkhapatra publication was printing its newspaper from two publication house located at Kathmandu and Biratnagar. More than 82\% of the newspapers were printed from the Kathmandu. Thus, this paper is entirely based upon the study and analysis with reference to the publication house at Kathmandu. Gorkhapatra being the newspaper run under the investment of Nepal Government is preferred by many Nepalese for genuine news about the government and activities being carried out by governmental bodies. There are five separate and distinct printing processes [20]. Among them lithographic printing is used in printing the newspaper. In offset lithographic printing the ink image is first transferred from the image carrier to the blanket and then to substrate.

\subsection{System Boundary}

Figure 1 shows the system boundary of the study. The boundary was limited to estimate carbon emissions from the manufacturing of raw materials, transportation of raw materials to publication houses and carbon emission in printing the newspaper and carbon emission in dispatching the newspaper from publication house to distributor.

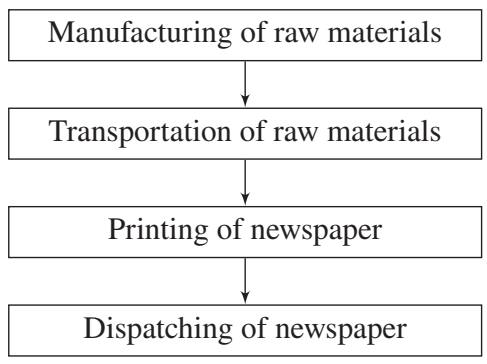

Figure 1: System boundary of carbon footprint of newspaper

\subsection{Methodology}

This research methodology is based upon the screening life cycle assessment of newspapers done as per the 'Life cycle assessment Requirements and guidelines' ISO 14044 (ISO 2006) [21]. The life assessment includes major activities and constituents during the analysis. The steps of the assessment are shown in Figure 2

During the assessment of the carbon footprint, the emissions during the manufacturing of major raw materials like paper, aluminum plate and ink were taken from various sources. The emissions due to the fuel consumption during the transportation of raw materials to publication house were considered, and the emissions due to

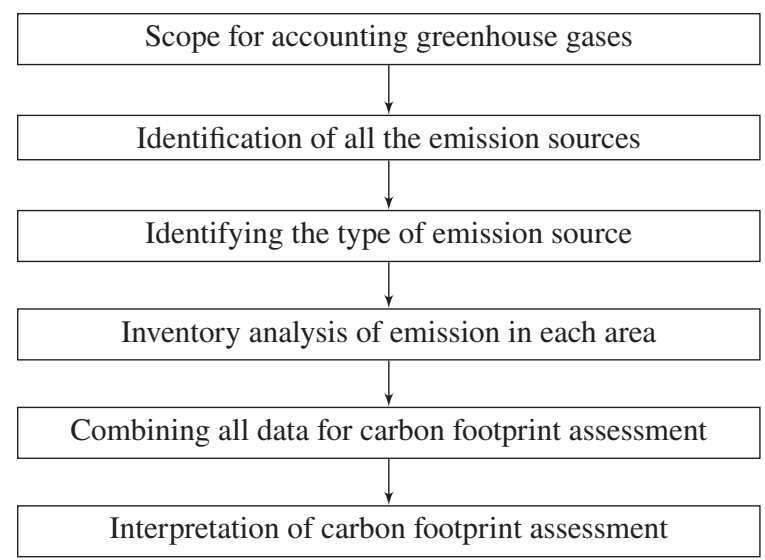

Figure 2: Flowchart showing the steps adopted during the assessment of carbon footprint

the power consumption in the printing of paper along with the emission due to the fuel consumption during the transportation of printed newspaper were taken into account of calculation.

\subsection{Calculation Method}

For calculating the overall emission of a newspaper, the emission at various stages were accounted and added as shown in Eq. 1.:

$$
\mathrm{E}=\sum\left(\mathrm{E}_{R}+\mathrm{E}_{C o}+\mathrm{E}_{C a}+\mathrm{E}_{P}+\mathrm{E}_{D N}\right)
$$

And,

$\mathrm{E}_{R} \quad=\mathrm{E}_{N}+\mathrm{E}_{I}$

$\mathrm{E}_{C o}=\mathrm{E}_{F}+\mathrm{E}_{L}+\mathrm{E}_{A}$

$\mathrm{E}_{C a}=\sum \mathrm{E}_{T}$

$\mathrm{E}_{T}=\mathrm{FCpKm} \times \mathrm{DT} \times \mathrm{FoT}$

$\mathrm{E}_{D N}=\mathrm{FCpKg} \times \mathrm{TWoN}$

$\mathrm{E}_{P}=\sum \mathrm{E}_{P C}$

Where,

E : Overall emission for the newspaper for a year

$\mathrm{E}_{R} \quad: \mathrm{E}_{\text {Raw materials }}$ is the carbon emission due to consumption of raw materials for a year. Newspaper and Ink are the major raw materials.

$\mathrm{E}_{\mathrm{Co}} \quad: \mathrm{E}_{\text {Consumables }}$ Consumables represents the carbon emission due to the chemicals used during printing like fountain solution, lubricants and aluminum plate used during lithographic offset printing. 


\begin{tabular}{|c|c|}
\hline $\mathrm{E}_{C a}$ & $\begin{array}{l}: \mathrm{E}_{\text {Carriageinwards }} \text { is the emission due to the } \\
\text { fuel consumed during the transportation } \\
\text { of raw materials and major consumable } \\
\text { items. }\end{array}$ \\
\hline $\mathrm{E}_{P}$ & $\begin{array}{l}: \mathrm{E}_{\text {Printing }} \text { represents the emission due to } \\
\text { power consumed during printing the news- } \\
\text { paper. }\end{array}$ \\
\hline $\mathrm{E}_{D N}$ & $\begin{array}{l}: \mathrm{E}_{\text {Dispatching Newspaper }} \text { represents the emis- } \\
\text { sion due to the fuel consumption during } \\
\text { the dispatch of printed newspapers. }\end{array}$ \\
\hline $\mathrm{E}_{N}$ & $: \mathrm{E}_{\text {Newsprint paper }}$ \\
\hline $\mathrm{E}_{I}$ & $: \mathrm{E}_{\mathrm{Ink}}$ \\
\hline $\mathrm{E}_{F}$ & : $\mathrm{E}_{\text {Fountainsolution }}$ \\
\hline $\mathrm{E}_{L}$ & : $\mathrm{E}_{\text {Lubricants }}$ \\
\hline $\mathrm{E}_{A}$ & : $\mathrm{E}_{\text {Aluminumplate }}$ \\
\hline $\mathrm{E}_{T}$ & $\begin{array}{l}\text { : Emission due to Transportation of Raw } \\
\text { Materials and Consumable Items }\end{array}$ \\
\hline FCpKm & : Fuel consumed per Km \\
\hline DT & : Distance Travelled \\
\hline FoT & : Frequency of Transportation \\
\hline FCpKg & : Fuel consumed per kg \\
\hline TWoN & : Total Weight of Newspaper \\
\hline $\mathrm{E}_{P C}$ & : Power Consumption \\
\hline
\end{tabular}

\subsection{Carbon Emission Factors}

The emission factors were derived from the various literature reviews since the local data were not available.

i The emission factor for the newspaper was taken as $1650 \mathrm{~kg} \mathrm{CO}_{2}$ e per ton considering $5 \%$ of recycled paper usage during paper manufacturing [22].

ii The emission factor for the printing ink was taken as $2.5 \mathrm{~kg} \mathrm{CO}_{2} \mathrm{e}$ per kg and for fount was taken as $2.0 \mathrm{~kg} \mathrm{CO}_{2}$ e per kg [23].

iii The emission factor for the electricity was taken assuming the electricity to be generated from the coal. For this, the emission factor is taken from the literature review of Indian research article. The emission factor is taken as $0.911 \mathrm{Kg} \mathrm{CO}_{2} \mathrm{e}$ per kWh obtained from the $250 \mathrm{MW}$ plant which was analyzed in a coal thermal plant in India over two years by Chakraborty et al. [24]. iv The emission factor for the petrol was taken as $2.45 \mathrm{~kg} \mathrm{CO}_{2} \mathrm{e}$ per liter and for the diesel $2.69 \mathrm{~kg}$ $\mathrm{CO}_{2} \mathrm{e}$ per liter was taken [25].

$\mathrm{v}$ The emission factor for the aluminum plate was taken as $16.5 \mathrm{~kg} \mathrm{CO}_{2} \mathrm{e}$ per $\mathrm{kg}$ [26]

vi The emission factor for the lubricants was taken as $2.82 \mathrm{~kg} \mathrm{CO}_{2}$ e per liter [27].

\subsection{Data Collection}

The data was mainly collected from the Gorkhapatra publication located at Kathmandu about the consumption of raw materials, chemicals, and power during the printing of newspapers. The information regarding the location of supplier and modes of transportation for the raw materials were also collected from the stores department of publication. For the calculation of fuel consumption during the transportation of raw materials from the dry port in Birgunj to publication house, random sampling was done for 30 trucks carrying cargo from Birgunj to Kathmandu and the fuel consumption per $\mathrm{kg}$ was calculated taking the mean of the samples. Similarly, the information regarding the number of readers across the country and the modes of transportation for dispatching printed newspapers were collected from the dispatch department. To calculate the fuel consumption in the transportation of printed newspapers across the 77 districts of Nepal, 30 random samples of bus were taken from the 19 bus routes from the district of publication: Kathmandu. For calculating the fuel consumption per kg, total weight of cargo and passengers in the bus was added and the total fuel consumption in the route was accounted.

\section{Result and Discussion}

\subsection{Consumption of raw materials}

The annual consumption of the raw materials like paper and ink for the printing of newspapers for the year 2019 A.D. were collected from the Gorkhapatra publication. Other necessary items include aluminum plate, fountain solution, lubrication, and source of power. The annual consumption of paper and ink are shown in Figure 3 and 4 , which shows the fluctuations throughout the year depending upon the sales and the volume of individual paper according to news content.

The annual consumption of standard newsprint paper and ink were found to be $847215 \mathrm{~kg}$ and $26795 \mathrm{~kg}$ over a period of one year.

\subsection{Transportation of Raw materials}

The mode of transportation for raw materials from supplier to publication is via road. The frequency of transportation for paper roll is 20 times per year, for alu- 


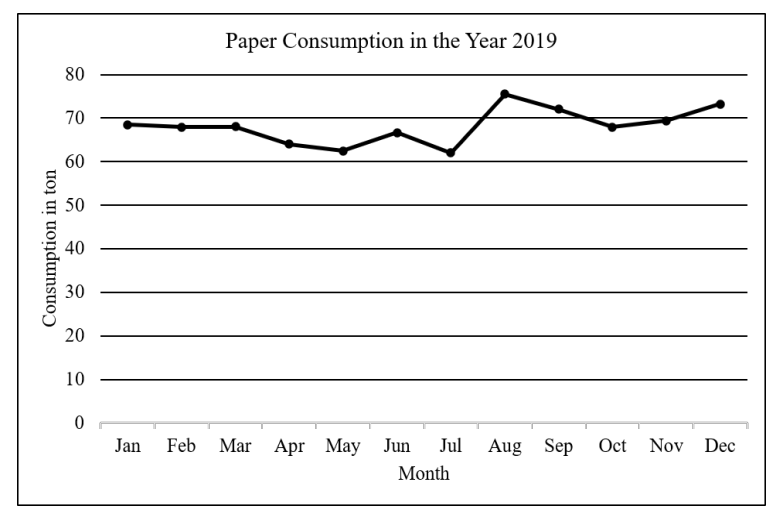

Figure 3: : Paper Consumption in the Year 2019 A.D.

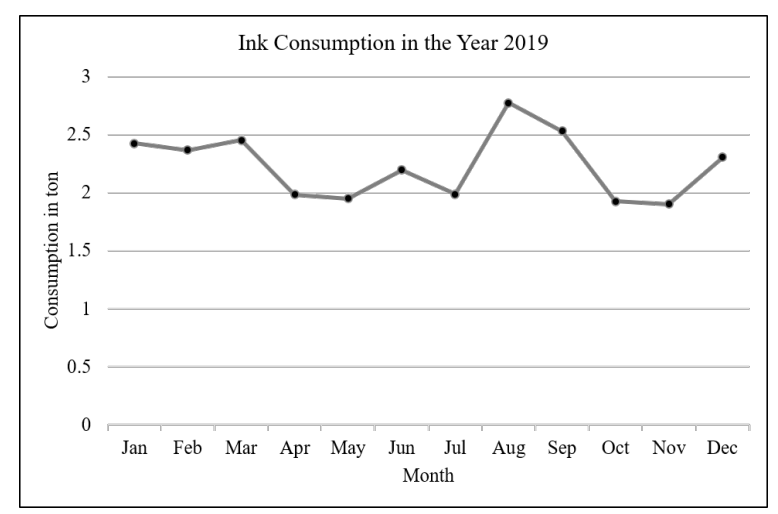

Figure 4: Ink Consumption in the Year 2019 A.D.

minum plates and ink is 1 time per year using 42-ton capacity containers from India to dry ports located in Birgunj of Nepal. The fuel consumption during the transportation from supplier to dry port is calculated using the standard fuel consumption taken from the fuel consumption statistics for heavy duty vehicles in India. [28]. For transporting the raw materials from dry port to publication house, 11-ton two axle right chassis truck is used which constitutes majority of total cargo transportation in Nepal. The frequency of paper roll is 77 times per year, for aluminum plates is 1 time per year and for ink is 3 times per year from the dry port to Kathmandu. For calculation of fuel consumption per kg during the transportation of raw materials from dry port to Kathmandu, a sample to 30 trucks were taken. The average of the sample was found to be 7.88 litre of diesel per $1000 \mathrm{~kg}$ cargo. Thus, the total carbon footprint during the transportation of raw materials to the publication house was found to be $53605.53 \mathrm{~kg} \mathrm{CO}_{2} \mathrm{e}$.

\subsection{Printing of Newspaper}

Newspapers are printed using the printing press which is run with electricity. The total electricity consumed by all the electrical appliances in the year 2019 A.D. was found to be $85714.29 \mathrm{kWh}$. In Gorkhapatra, the electricity used during printing is obtained from hydroelectricity which is green energy, thus the total carbon emission in printing is zero for the Scenario I. However, if the same printing activity is done using the electricity obtained from coal thermal plant, then the total carbon emission during printing will be equal to $78000 \mathrm{~kg} \mathrm{CO}_{2} \mathrm{e}$ in the Scenario II. Annually, $9321.85 \mathrm{Kg}$ of aluminum plate of dimension $546 \mathrm{~mm} \times 720 \mathrm{~mm} \times 0.35 \mathrm{~mm}$ is used for offset printing. The annual consumption and equivalent $\mathrm{CO}_{2}$ emissions from different sources are shown in Table 1.

\subsection{Dispatching of Newspaper}

The newspaper readers of the Gorkhapatra are present throughout the geography of Nepal as shown in Figure 5. The printed newspapers are distributed from the printing press located in Kathmandu to the predefined delivery points across various parts of Nepal via road transportation. The delivery of newspaper from the delivery points to the customers is done via bicycle or hand to hand distribution. For calculation of fuel consumption per kg during the delivery of printed newspapers, fuel consumption per $\mathrm{kg}$ was calculated among the 30 buses in various bus routes and the mean of the sample was taken. The total fuel consumption was calculated to be 15067.73 litre of diesel over a year which is equivalent to $40532.2 \mathrm{~kg} \mathrm{CO}_{2} \mathrm{e}$.

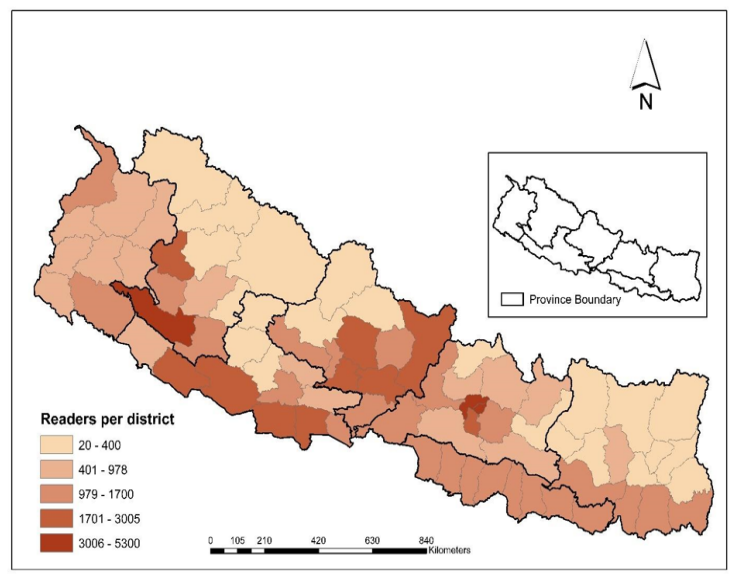

Figure 5: Reader Distribution of Gorkhapatra across Nepal [29]

\subsection{Total Carbon Emissions}

In first scenario, the total carbon emission in printing is zero. The carbon emission from the manufacturing of raw materials and consumables comprises $89.68 \%$ of total emission. The carbon emission during the transportation of raw materials and dispatch of printed newspapers comprises $2.96 \%$ and $2.24 \%$ respectively. 
Analysis on carbon footprint: A Case Study of Gorkhapatra National Daily in Nepal

Table 1: Emission source and their respective carbon footprint

\begin{tabular}{lllllll}
\hline S.N. & Emission Source & Unit & Annual Consumption & $\begin{array}{l}\text { Emission Factor } \\
\left(\mathrm{kg} \mathrm{CO}_{2} \mathrm{e} / \text { unit }\right)\end{array}$ & $\begin{array}{l}\text { Ton } \mathrm{CO}_{2} \text { Equivalent }\left(\mathrm{tCO}_{2} \mathrm{e}\right) \\
\text { Scenario I }\end{array}$ & Scenario II \\
\hline 1 & Srandard Newsprint paper & Ton & 847.22 & 1650.00 & 1397.90 & 1397.90 \\
2 & Ink & Ton & 26.80 & 2500.00 & 66.99 & 66.99 \\
3 & Aluminum plate & Ton & 9.32 & 16500.00 & 153.81 & 153.81 \\
4 & Fountain Solution & Ton & 1.34 & 2000.00 & 2.68 & 2.68 \\
5 & Lubricant & $\mathrm{L}$ & 500.00 & 2.82 & 1.41 & 1.41 \\
6 & Electricity Consumption & $\mathrm{kWh}$ & 85714.29 & 0.91 & 0.00 & 78.00 \\
7 & Petrol Consumption & $\mathrm{L}$ & 18000.00 & 2.45 & 44.10 & 44.10 \\
8 & Diesel Consumption & $\mathrm{L}$ & 18000.00 & 2.69 & 48.42 & 48.42 \\
\hline
\end{tabular}

As the newspaper are one of the basic need of people, the newspaper must be printed even if there is not supply of green energy. In the second scenario, it is assumed that the electricity used during printing is obtained from a coal thermal plant. The power consumed in printing the newspaper comprises $4.13 \%$. The carbon emission from the manufacturing of raw materials and consumables comprises $85.97 \%$ of total emission. The carbon emission during the transportation of raw materials and dispatch of printed newspapers comprises $2.84 \%$ and $2.15 \%$ respectively. The power consumed in printing the newspaper comprises $4.13 \%$.

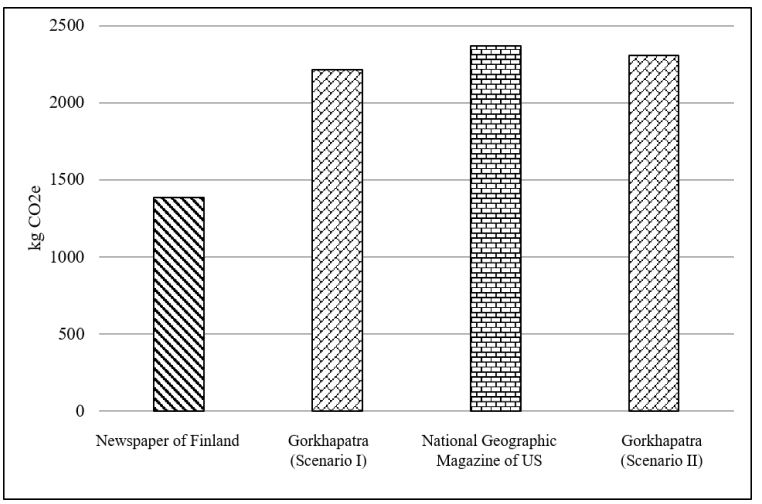

Figure 6: Comparison of Carbon Footprint of Gorkhapatra with Other Newspapers

Combining all the individual inventories the cumulative carbon footprint of Gorkhapatra newspaper was found to be $2212.1 \mathrm{~kg} \mathrm{CO}_{2} \mathrm{e}$ per ton which is equivalent to $59.37 \mathrm{~g} \mathrm{CO}_{2}$ e per unit newspaper for the first scenario. For the second scenario, the cumulative carbon footprint of Gorkhapatra newspaper was found to be 2308.5 $\mathrm{kgCO}_{2} \mathrm{e}$ per ton which is equivalent to $61.92 \mathrm{~g} \mathrm{CO}_{2} \mathrm{e}$ per unit newspaper. A similar research in the US on life cycle carbon footprint of National Geographic magazine has shown the carbon footprint as $2370 \mathrm{~kg} \mathrm{CO}_{2} \mathrm{e}$ per ton [22]. Another research carried out in Finland considering $100 \%$ landfill disposal of newspapers has

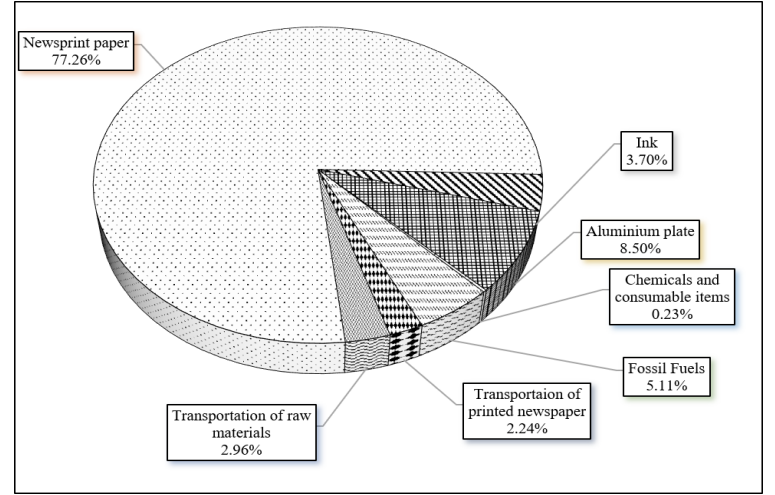

Figure 7: Percentage Wise Distribution of Carbon Footprint of Newspaper (Scenario I)

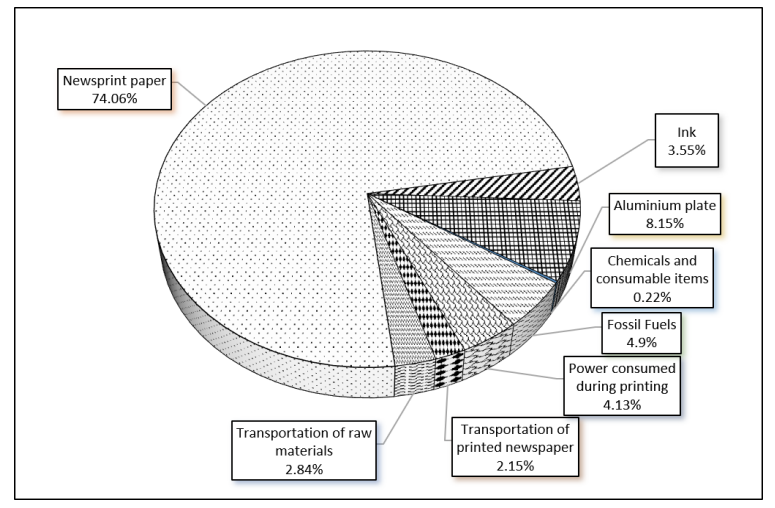

Figure 8: Percentage Wise Distribution of Carbon Footprint of Newspaper (Scenario II)

the carbon footprint is in the range of $1360-1410 \mathrm{~kg}$ $\mathrm{CO}_{2} \mathrm{e}$ per ton. Additionally, the same research shows the carbon footprint of the book in Finland is approximately $2300 \mathrm{~kg} \mathrm{CO}_{2}$ e per ton. Due to high involvement of green energy in Finland the first scenario of study is compared with the newspaper of Finland. The very less amount of emission in newspapers in Finland might be due to the high volume of green energy involved in the 
electricity grid [30]. As coal thermal plant has more share on electricity in the United States, the second scenario is shown in comparison to National Geographic magazine.

\subsection{Prospects of Reduction in $\mathrm{CO}_{2}$ Emissions}

With the evolution of concept of reducing GHGs for sustainability of the world, the global debates have time and again pointed the use of paper printing and paper-based products as environment destructive medium, notwithstanding the fact that many of the printing media are now operating on renewable energy. Though there is use of electricity in printing, there are many common steps that can be adopted in Gorkhapatra Sansthan to bring down the negative influence on environment by controlling process wastes in energy, printing substrates, ink, wash up solvents, etc.

Most of the electricity used for printing is expended during the operation of motor drives in machines. Use of energy efficient motors in the machines can contribute significantly to reduce energy consumption. Adoption of news technologies for faster presses, cutters and trimmers can increase productivity and flexibility in printing process. Shifting towards the use of high productivity web presses which operate at higher speed of 3000 feet per minute and use of wide web press format to reduce the number of makereadies, wastes can be beneficial in reducing carbon footprint. [31, 32]. Installation of press temperature controls having potential to eliminate variables causing deficiencies and inconsistencies in offset printing to correct wastes and reworks can be executed [33]. Substituting incandescent lights with high energy efficient compact fluorescent lamps (CFL) and light emitting diodes (LED) bulbs in the entire factory can also reduce emissions.

Reduction in the internal paper losses through a better stock management can be done to reduce paper losses. Changes in the font size, line spacing and margins, reducing header and footer, eliminating redundant texts from reports and articles as well as reducing the size of images can lessen the bulk of paper consumption. Further, use of recycled paper in the place of fresh rolls for printing can ultimately reduce the carbon emissions. Reviewing the paper quality in terms of gram per square meter and carbon emissions can also be done to reduce contribution of paper in overall carbon footprint newspaper. Regular energy audit supported by proper planning and implementation could be a path stream for $\mathrm{CO}_{2}$ neutralized print for Gorkhapatra Sansthan.

\section{Conclusion}

This study demonstrated a screening life cycle assessment approach for evaluating the carbon footprint of national newspaper in the context of Nepal. The results indicated that the carbon footprint of printing a $1000 \mathrm{~kg}$ newspaper was $2213.1 \mathrm{~kg} \mathrm{CO}_{2} \mathrm{e}$ and $2308.5 \mathrm{~kg} \mathrm{CO}_{2} \mathrm{e}$ for scenario I and scenario II respectively. The carbon footprint of one ton of newspaper, considering scenario II is equivalent to carbon sequestrated by three hundred sixty-four 25-years old pine trees over a period of one year [34]. This study provides a framework for studying carbon emission reduction potential of the newspaper. Similarly, this research also promotes the development of mechanisms for the local inventory analysis on carbon emission. For the future carbon reduction in the newspaper, it is essential to reduce fossil fuel energy consumption as well as improve energy efficiency. This research also provides avenues for recycling of newspaper to cut off national carbon emission from newspaper. In addition, future research can be done to analyze the benefit of using e-paper over printed newspaper in terms of carbon emissions.

\section{Acknowledgement}

We would like to express our deepest appreciation to the Gorkhapatra Publications for providing an excellent platform to carry out our research. We are indebted to all the staffs of Gorkhapatra Sansthan, specially to Mr. Krishna Murari Bhandari, Mr. Arjun Tamang and Mr. Tara Bahadur Basyal, for their support to acquire necessary information for this paper. We would like to express our appreciation to all the respondents for giving their valuable information. We owe our deepest gratitude to all those who have directly and indirectly assisted in this paper.

\section{References}

[1] Masson-Delmotte, V., P. Zhai, H.-O. Pörtner, D. Roberts, J. Skea, P.R. Shukla, A. Pirani, W. Moufouma-Okia, C. Péan, R. Pidcock, S. Connors, J.B.R. Matthews, Y. Chen, X. Zhou, M.I. Gomis, E. Lonnoy, T. Maycock M T, Waterfield T. Summary for Policymakers. In: Global Warming of $1.5^{\circ} \mathrm{C}$. An IPCC Special Report on the impacts of global warming of $1.5^{\circ} \mathrm{C}$ above pre-industrial levels and related global greenhouse gas emission pathways, in the context of strengthening the global response to the threat of climate change, sustainable development, and efforts to eradicate poverty: 3[R]// One Earth. World Meteorological Organization, 2019: 374-381.

[2] ADB. Solid Waste Management in Nepal: Current Status and Policy Recommendations[R/OL]// Asian Development Bank (ADB). 2013: 1-56. http://cpfd.cnki.com.cn/ Article/CPFDTOTAL-ZGKL200509001593.htm\{\%\}0Ahttps: //www.adb.org/sites/default/files/publication/30366/solidwaste-management-nepal.pdf.

[3] Food and Agriculture Organization UN. Forests and Climate 
Change[EB/OL]. [20 Dec 2020]. http://www.fao.org/3/ac836e/ AC836E03.htm.

[4] UK Parliamentary Office of Science and Technology. UK Parliamentary Office of Science and Technology POST[R]. 2006.

[5] Lopes E, Dias A, Arroja L, et al. Application of life cycle assessment to the Portuguese pulp and paper industry[J/OL] . Journal of Cleaner Production, 2002, 11(1): 51-59. DOI: https: //doi.org/10.1016/S0959-6526(02/00005-7.

[6] Das T K, Houtman C. Evaluating chemical-, Mechanical-, and bio-pulping processes and their sustainability characterization using life-cycle assessment[J/OL]. Environmental Progress, 2004, 23(4): 347-357. DOI: https://doi.org/10.1002/ep.10054.

[7] González-García S, Berg S, Feijoo G, et al. Environmental impacts of forest production and supply of pulpwood: Spanish and Swedish case studies[J/OL]. International Journal of Life Cycle Assessment, 2009, 14(4): 340-353. DOI: https://doi.org/ 10.1007/s11367-009-0089-1.

[8] Sevigné-Itoiz E, Gasol C M, Rieradevall J, et al. Methodology of supporting decision-making of waste management with material flow analysis (MFA) and consequential life cycle assessment (CLCA): Case study of waste paper recycling[J/OL]. Journal of Cleaner Production, 2015, 105: 253-262. DOI: https://doi.org/ 10.1016/j.jclepro.2014.07.026.

[9] Li Y, Zhang M, Deng S. Life cycle assessment of Forestry (Pulp) and Paper-making industry[J/OL]. Advanced Materials Research, 2010, 113-116: 1496-1499. DOI: https://doi.org/ 10.4028/www.scientific.net/AMR.113-116.1496.

[10] Gemechu E D, Butnar I, Gomà-Camps J, et al. A comparison of the GHG emissions caused by manufacturing tissue paper from virgin pulp or recycled waste paper[J/OL]. International Journal of Life Cycle Assessment, 2013, 18(8): 1618-1628. DOI: https://doi.org/10.1007/s11367-013-0597-x.

[11] Mourad A L, Da Silva H L G, Nogueira J C B. Life cycle assessment of cellulose packaging materials production: Folding box board and kraftliner paper[J/OL]. International Journal of Life Cycle Assessment, 2014, 19(4): 968-976. DOI: https://doi.org/10.1007/s11367-013-0690-1.

[12] Gupta R. Project Report on carbon footprint for newspaper industry[R].

[13] Tenhunen M, Penttinen E. Assessing the carbon footprint of paper vs. electronic invoicing[R]// ACIS 2010 Proceedings 21st Australasian Conference on Information Systems. 2010.

[14] Yue W, Cai Y, Su M, et al. Carbon Footprint of Copying Paper: Considering Temporary Carbon Storage Based on Life Cycle Analysis[J/OL]. Energy Procedia, 2017, 105: 3752-3757. DOI: https://doi.org/10.1016/j.egypro.2017.03.870.

[15] Esquer J, Vaeza-Gastélum C, Remmen A, et al. Life cycle assessment for printed newspapers in Northwestern Mexico[J/OL]. International Journal of Sustainable Development and World Ecology, 2015, 22(3): 259-268. DOI: https://doi.org/10.1080/ 13504509.2015.1020456.

[16] Springer A, Ag V. A Life Cycle Assessment of the production of a daily newspaper and a weekly magazine[R]// Technology. 1998.

[17] Dias A C, Arroja L, Capela I. Life cycle assessment of printing and writing paper produced in Portugal[J/OL]. International Journal of Life Cycle Assessment, 2007, 12(7): 521-528. DOI: https://doi.org/10.1065/lca2006.08.266.

[18] Rafenberg C, Mayer E. Life cycle analysis of the newspaper Le MONDE[J/OL]. International Journal of Life Cycle Assessment, 1998, 3(3): 131-144. DOI: https://doi.org/10.1007/ BF02978822.

[19] Ministry of Finance. Economic survey 2017/18[R]. Kathmandu, Nepal: Government of Nepal.

[20] Caselli M, de Gennaro G, Saracino M R, et al. Indoor contaminants from newspapers: VOCs emissions in newspaper stands[J/OL]. Environmental Research, 2009, 109(2): 149-157. DOI: https://doi.org/10.1016/j.envres.2008.10.011.
[21] International Organization for Standardization (ISO). Environmental management: Life cycle assessment; requirements and guidelines[R]. Geneva, 2006.

[22] Boguski T K. Life cycle carbon footprint of the National Geographic magazine[J/OL]. International Journal of Life Cycle Assessment, 2010, 15(7): 635-643. DOI: https://doi.org/ 10.1007/s11367-010-0210-5.

[23] Amon-Tran I, Anayath R, Pai A S, et al. An Approach to Minimize Carbon Footprint for an Environmental Friendly Printing by Optimizing an Offset Machine in a Printing Facility[J/OL]. Procedia - Social and Behavioral Sciences, 2012, 37: 514-527. DOI: https://doi.org/10.1016/j.sbspro.2012.03.316.

[24] Chakraborty N, Mukherjee I, Santra A K, et al. Measurement of $\mathrm{CO} 2, \mathrm{CO}, \mathrm{SO} 2$, and $\mathrm{NO}$ emissions from coal-based thermal power plants in India[J/OL]. Atmospheric Environment, 2008, 42(6): 1073-1082. DOI: https://doi.org/, 10.1016/ j.atmosenv.2007.10.074.

[25] Ministry for the Environment. Mesuring Emissions: A Guide for Organisations. 2020 Summary of Emission Factors[R/OL]. Wellington: New Zealand Government, 2020: 27. http: //library1.nida.ac.th/termpaper6/sd/2554/19755.pdf.

[26] Hao H, Geng Y, Hang W. GHG emissions from primary aluminum production in China: Regional disparity and policy implications[J/OL]. Applied Energy, 2016, 166: 264-272. DOI: https://doi.org/, 10.1016/j.apenergy.2015.05.056.

[27] US Environmental Protection Agency. Emission factors for greenhouse gas inventories." Stationary Combustion Emission Factors[R]. 2014.

[28] Karali N, Gopal A R, Sharpe B, et al. Improved heavy-duty vehicle fuel efficiency in India: Benefits, costs and environmental impacts[J/OL]. Lawrence Berkeley National Lab, 2017 (April): 1-25. http://eta-publications.lbl.gov/sites/default/files/ 1bnl-2001017.pdf.

[29] Department of Survey. Map of Nepal[R]. Kathmandu, Nepal: Government of Nepal, 2020.

[30] Pihkola H, Nors M, Kujanpää M, et al. Carbon footprint and environmental impacts of print products from cradle to grave: Results from the LEADER project (Part 1)[J]. VTT Tiedotteita - Valtion Teknillinen Tutkimuskeskus, 2010(2560): 1-253.

[31] Graphic Arts Technical Foundation. 1994 Technology Forecast[R]. Pittsburgh, PA, 1994.

[32] Petersen D. Punching Up Productivity[J]. American Printer, 1993: 34-36.

[33] Bruno M. What's New In Graphic Communications[R]. Bradenton, FL, 1993.

[34] Toochi E C. Carbon sequestration: how much can forestry sequester $\mathrm{CO} 2$ ? [J/OL]. Forestry Research and Engineering: International Journal, 2018, 2(3). DOI: https://doi.org/10.15406/ freij.2018.02.00040. 